\title{
Phosphatidylcholine:Ceramide Cholinephosphotransferase 1
}

National Cancer Institute

\section{Source}

National Cancer Institute. Phosphatidylcholine:Ceramide Cholinephosphotransferase 1. NCI Thesaurus. Code C105018.

Phosphatidylcholine:ceramide cholinephosphotransferase 1 (419 aa, $\sim 49 \mathrm{kDa}$ ) is encoded by the human SGMS1 gene. This protein plays a role in apoptosis. 